\title{
Removal of Aluminium in Contaminated Soil using Locally Isolated Vibrio alginolyticus
}

\author{
Ipung Fitri Purwanti', Setyo Budi Kurniawan ${ }^{2 *}$, Devita Yulisa Simanjuntak ${ }^{1}$ \\ 1 Department of Environmental Engineering, Faculty of Civil, Environmental and Geo Engineering, Institut \\ Teknologi Sepuluh Nopember, Kampus ITS Sukolilo, Surabaya 60111, Indonesia \\ 2 Politeknik Perkapalan Negeri Surabaya, Jalan Teknik Kimia, Kampus ITS Sukolilo, Surabaya 60111, Indonesia \\ * Corresponding author's e-mail: setyobudi.kurniawan@gmail.com
}

\begin{abstract}
The aluminium contaminated soil is currently being a concern due to the use of aluminium waste as a material for building roads and river dams in Jombang District, Jawa Timur Province, Indonesia. This application was debated because aluminium waste is categorized as hazardous waste. One widely known method for treating the metal contaminated soil is bioremediation. One potential indigenous bacterial species to remove aluminium, Vibrio alginolyticus was isolated from contaminated soil. A toxicity test to $V$. alginolyticus showed that this bacterium could grow in aluminium contaminated soil until $100 \mathrm{mg} / \mathrm{L}$ equal to $48 \mathrm{mg} / \mathrm{kg}$ concentration. The removal of aluminium from soil was conducted by using 50 and $100 \mathrm{mg} / \mathrm{L}$ concentration. The result showed that the addition of $2 \% \mathrm{v} / \mathrm{v}$ of $V$. alginolyticus can remove $5.48 \%$ aluminium from $100 \mathrm{mg} / \mathrm{L}$ contaminated soil initial concentration after 12 days of test period. The addition of $V$. alginolyticus did not significantly influence the removal of aluminium from contaminated soil $(\mathrm{p}>0.05)$.
\end{abstract}

Keywords: aluminium, bacteria, bioremediation, indigenous, $V$. alginolyticus.

\section{INTRODUCTION}

Aluminium ( $\mathrm{Al})$ is the most abundant metal in the Earth's crust and the third most abundant element after oxygen and silicon (Tsakiridis, 2012). Aluminium is found as a compound which is the main constituent of bauxite, in the form of a mixture of oxides and aluminium hydoxide (Sugiyarto, 2003). Aluminium is widely used in various fields of life such as transportation, construction, and household appliances. The transportation sector, especially in the aerospace industry, benefits greatly from the high strength of aluminium (Pina and Cervantes, 1996). In the industrial sector, drugs such as antacid tablets contain several hundred milligrams of aluminium hydroxide and food additives in the form of Sodium Aluminium Phosphate (SALPs) (Lopez et al., 2002).

The chemical structure and solubility of $\mathrm{Al}$ are influenced by such environmental factors as $\mathrm{pH}$. At $\mathrm{pH}$ below neutral, $\mathrm{Al}$ is in an insoluble state as $\mathrm{Al}(\mathrm{OH})_{3}$. Because of the acidification process, $\mathrm{Al}(\mathrm{OH})_{3}$ changes to dissolved ions such as $\mathrm{Al}(\mathrm{OH})_{4}^{-}, \mathrm{Al}(\mathrm{OH})_{2}^{+}, \mathrm{AlOH}^{+2}$, and $\mathrm{Al}^{+3}$. At $\mathrm{pH}$ below or lower, aluminium turns into soluble and toxic to microorganisms and plants (Akhbarzadeh and Shariati, 2014)(Chau et al., 2014). Although aluminium is not included in the main environmental pollutants, it can be found in most industrial wastes, including the ones from mining activities, metal processing activities, and manufacturing (Ojumu et al., 2006). Some aluminium recycling industries in Sumobito Sub-District, Jombang District, Jawa Timur Province, Indonesia produce solid waste (slag) which has the potential to pollute water and soil. The waste that is produced from these industries was directly discharged into environment without any treatment (Laksono and Muzayanah, 2016). Several complains, such as the decreasing of agricultural soil fertility and the changing of ground water color, have been reported by the surrounding residents.

Removal of metal contaminants can be carried out in two ways, namely biological and 
physicochemical methods. The physicochemical methods are ineffective in local communities because they generate expensive costs, high energyconsumption, and quite a lot of chemical reagents. This is the main reason why the use of microorganisms is preferred in the process of removing of metal contaminants (Hamdi et al., 2007). The biological methods can restore polluted water and soil using living things such as plants, yeast, fungi, and bacteria (Kumar et al., 2010). This biological method can be an alternative because it is relatively cheap, environmentally friendly, and provides considerable removal efficiency. Some microorganisms can adapt to contaminants and have a resistance system (Giovanell et al., 2017). Bacteria are microorganisms that have the ability to withstand the presence of metals at certain concentrations (Purwanti et al., 2018). This ability can be further investigated for the development of strategies for removing metals in a contaminated environment (Giovanell et al., 2017).

Vibrio alginolyticus had been reported to have a good potential in removing aluminium from contaminated wastewater (Kurniawan et al., 2018). To the best of our knowledge, a research on the ability of Vibrio alginolyticus in removing aluminium from contaminated soil had not been widely conducted yet. On the basis of this consideration, we undertook this research to analyze the potential of Vibrio alginolyticus to remove aluminium from contaminated soil.

\section{MATERIALS AND METHOD}

\section{Preparation of $\mathrm{AlCl}_{3}$ solution}

The pollutant solution used in this study was $\mathrm{AlCl}_{3}$. The stock solution was made by diluting $4.94 \mathrm{~g}$ of $\mathrm{AlCl}_{3}$ (SAP, Indonesia) in $1 \mathrm{~L}$ of distilled water to make a concentration of $1000 \mathrm{mg} / \mathrm{LAlCl}_{3}$ (Purwanti et al., 2018). Aluminium stock solution was sterilized using autoclave (Memert+, Germany) at a pressure of $1.1 \mathrm{~atm}$ for 15 minutes (Kubyshkina et al., 2011). Sterile stock solutions will be mixed with soil to make aluminium contaminated soil using spike method (Purwanti et al., 2015).

\section{Soil density and holding capacity test}

The type of soil used in this study was garden soil. Soil density is calculated by taking $50 \mathrm{~mL}$ of garden soil using a glass funnel (Pyrex, Germany). The soil weight was then measured using an analytical balance (OHAUS, China). The value of soil density was calculated by dividing the value of soil mass and soil volume. The value of soil density was obtained in units of mass/volume $(\mathrm{g} / \mathrm{mL})$ (Purwanti et al., 2017).

The holding capacity of soil was used to determine the volume capacity of pollutants that can be accommodated so that the soil is contaminated evenly. A soil holding capacity test was carried out by pouring stock solution into $10 \mathrm{~g}$ of soil in a glass funnel until the first drop of solution dripping from the bottom of the funnel. The value of the retention capacity was calculated by dividing the volume of stock solution added to the soil mass used (Purwanti et al., 2017). The value of holding capacity was obtained in units of volume $/ \mathrm{mass}(\mathrm{mL} / \mathrm{g})$.

\section{The making of aluminium contaminated soil}

The method of making aluminium contaminated soil was spiked method (Purwanti et al., 2015). The garden soil was first dried manually under the sun for 2 (two) days. The soil was then sieved using a 60 mesh sieve to obtain a uniform grain size. The addition of aluminium stock solution with concentrations of $0,50,100,200$, 350 and $500 \mathrm{mg} / \mathrm{L}$ was carried out based on soil holding capacity. These concentrations of aluminium were equal to $0,24,48,94,165$, and $235 \mathrm{mg} \mathrm{Al} / \mathrm{Kg}$ of soil.

\section{Bacterial regrowth}

$V$. alginolyticus isolates used in this study originated from the aluminium recycling industry area in Jombang District (Kurniawan et al., 2018). Bacterial regrowth was carried out using streaking method (Machmud, 2001). Bacterial regrowth was carried out onto Nurient Agar (Merck, Germany) medium and incubated at $37^{\circ} \mathrm{C}$ for 24 hours. After incubation for 24 hours, $V$. alginolyticus was transferred to Nutrient Broth liquid medium (Mercks, Germany) and shaken in a rotary shaker (Memert+, Germany) for 6 (six) hours at $150 \mathrm{rpm}$. The bacteria were then centrifuged using a $4000 \mathrm{rpm}$ (Biotek, China) centrifuge for 10 minutes. Separate bacterial pellet was then dissolved in $\mathrm{NaCl}$ (Mercks, Germany) $0.85 \%$. A trial and error was then carried out using a spectrophotometer (Innova2000, Germany) at a wavelength of $600 \mathrm{~nm}$ to obtain OD values (Optical Density) of $0.5 \mathrm{~A} \pm 0.005$ (Purwanti et al., 2017). 


\section{Preliminary toxicity test of aluminium contaminated soil}

Preliminary toxicity tests were carried out by adding $2 \% \mathrm{v} / \mathrm{v}$ of $V$. alginolyticus to the aluminium-contaminated soil in $250 \mathrm{~mL}$ Erlenmeyer (Pyrex, Germany) (Kurniawan et al., 2018). The volume addition of bacteria was $1 \mathrm{~mL}$. The $\mathrm{AlCl}_{3}$ concentrations were $0,50,100,200,350$, and $500 \mathrm{mg} / \mathrm{L}$. The polluted soil and bacteria then shook using a shaker (Innova2000, China) at a speed of $150 \mathrm{rpm}$ for 24 hours (Purwanti et al., 2017). The results of preliminary toxicity tests were observed by analyzing the growth of $V$. alginolyticus at each aluminium concentration. The bacterial growth was analyzed by calculating total bacterial colonies in soil at 0 and 24 hours test period using CFU method.

\section{Removal of aluminium from contaminated soil}

The removal of aluminium from the contaminated soil was carried out using a glass reactor (12 cm diameter $\times 23 \mathrm{~cm}$ height). A total of $2 \mathrm{~kg}$ contaminated soil was used for each reactor. Four different additional volumes of bacteria used in this stage were $0,2 \%, 5 \%$ and $10 \%$ (Kurniawan et al., 2017). Two different concentrations of aluminium contaminated soil (chosen from preliminary test) and one control concentration $(0 \mathrm{mg} / \mathrm{L})$ were used as concentration to be tested in this stage. The $\mathrm{pH}$ inside each reactor was adjusted to 5 by adding $\mathrm{CH}_{3} \mathrm{COOH}$ (Merck, Germany). This $\mathrm{pH}$ was chosen based on Kurniawan et al. (2017) which was the optimum condition for $V$. alginolyticus growth. The addition of
$\mathrm{CH}_{3} \mathrm{COOH}$ was also used to provide readily biodegradable carbon (Chau et al., 2014). The removal of aluminium test was conducted for 12 days (Chau et al., 2014). The parameters of total colonies and total aluminium in reactor were tested on day $0,4,8$ and 12 . Total aluminium parameter was tested by using ICP-OES (ThermoFisher, Japan). The aluminium removal percentage was calculated for each reactor by subtracting the aluminium initial concentration with final concentration.

\section{RESULTS AND DISCUSSION}

\section{Preliminary toxicity test of aluminium contaminated soil}

The toxicity of aluminium contaminated soil was determined by analyzing the bacterial growth inside reactors. On the basis of Figure 1, it can be seen that the $\log \mathrm{CFU}$ at 0 hours at the reactor with the addition of $0,50,100,200,350 \mathrm{mg} / \mathrm{L}$ aluminium sequentially of $8.07,8.45,8.47,8.33$, and 8.28. These values were derived from the addition of $V$. alginolyticus isolates carried out in uniform quantities $(2 \% \mathrm{v} / \mathrm{v})$. The control reactor without the addition of $\mathrm{AlCl}_{3}$ showed the growth of $V$. Alginolyticus, Log CFU was increased from 8.07 to 8.17 after 24 hours. This showed that bacteria can grow inside unpolluted conditions as control. Increased bacterial colonies also occured in the reactor with the addition of $50 \mathrm{mg} / \mathrm{L}$ aluminium. The increase in colony occured because the additional bacteria were still able to perform growth and metabolism by the addition of $50 \mathrm{mg} / \mathrm{L}$ aluminium.

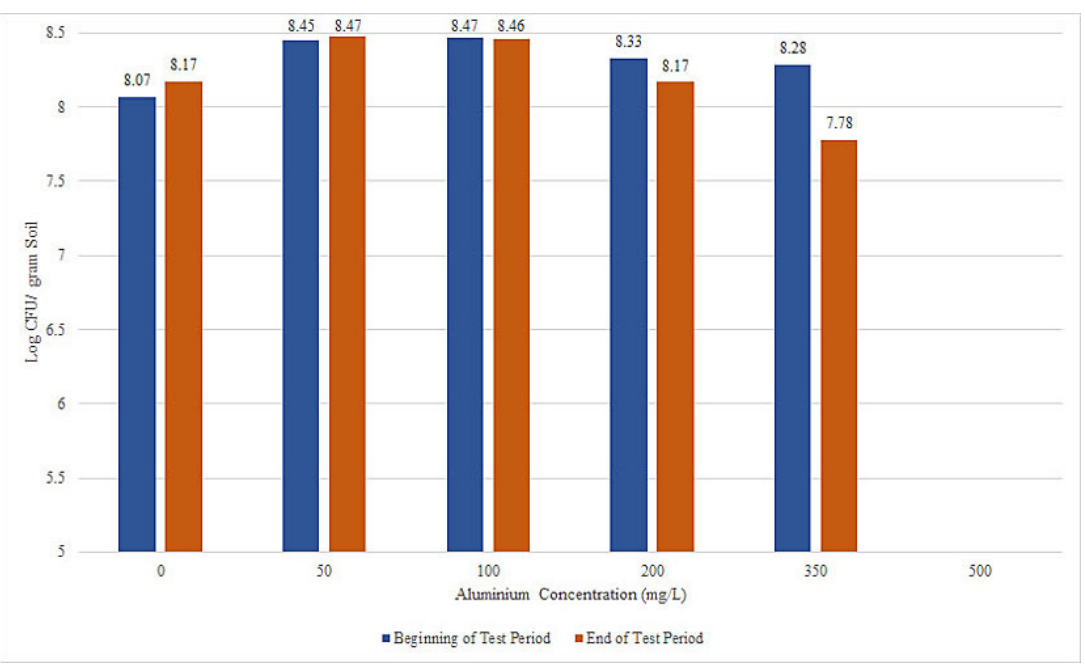

Figure 1. Number of bacterial colonies during preliminary test 
The decreases in Log CFU occurred in the reactor with the addition of $\mathrm{AlCl}_{3}$ of 100,200 , and $350 \mathrm{mg} / \mathrm{L}$ aluminium after 24 hours of test period. In the reactor with the addition of $100 \mathrm{mg} / \mathrm{L}$ aluminium, there was a decrease in Log CFU of 0.006 equal to $4 \times 10^{6}$ colonies. A greater decrease in Log CFU occured in the reactor of $200 \mathrm{mg} / \mathrm{L}$ aluminium by $1.9 \%$. The largest decrease in Log CFU occurred in the reactor with the addition of $350 \mathrm{mg} / \mathrm{L}$ aluminium that reached 0.504 equal to $131 \times 10^{6}$ colonies. Martins et al. (2012), stated that certain concentration of $\mathrm{Al}$ can cause toxicity that can inhibit the growth of microorganisms. On the basis of these results, it was known that the addition of $100 \mathrm{mg} / \mathrm{L}$ aluminium has been able to inhibit the growth of $V$. alginolyticus. The greater the addition of aluminium, the greater the total decrease in bacterial colonies inside tested reactors.

$V$. alginolyticus colony growth showed different characteristics in the reactor with the addition of $500 \mathrm{mg} / \mathrm{L}$ aluminium. On the basis of the analysis of total bacterial colonies, there were no bacterial colonies growing at 0 and 24 hours. This indicates that the addition of $500 \mathrm{mg} / \mathrm{L}$ aluminium has been able to totally inhibit the bacterial growth since the beginning of test period (Kurniawan et al., 2018). According to the analysis of total bacterial colonies growth in tested reactors, the concentrations of 50 and 100 were chosen to be used in Removal of Aluminium Test. These concentrations were chosen based on the statistical analysis which showed that the bacterial growth in reactor with the addition of 0,50 and $100 \mathrm{mg} / \mathrm{L}$ aluminium were not significantly different $(\mathrm{p}>0.05)$.

\section{Removal of aluminium from contaminated soil}

Figure 2 showed Log CFU in all tested reactors with,
$\mathrm{V}$ : Additional volume of $V$. alginolyticus
$\mathrm{C}$ : Aluminium concentration
$\mathrm{C} 0$ : Without aluminium addition
$\mathrm{C} 1$ : Addition of $50 \mathrm{mg} / \mathrm{L}$ aluminium
$\mathrm{C} 2$ : Addition of $100 \mathrm{mg} / \mathrm{L}$ aluminium
V0 : Without $V$. alginolyticus addition
$\mathrm{V} 1$ : Addition of $2 \% \mathrm{v} / \mathrm{v}$ V. alginolyticus
$\mathrm{V} 2$ : Addition of $5 \% \mathrm{v} / \mathrm{v} V$. alginolyticus
V3 : Addition of $10 \% \mathrm{v} / \mathrm{v}$ V. alginolyticus

Figure 2 showed that the Log CFU in the control reactor without the addition of $V$. alginolyticus and aluminum (V0C0) tend to increase and decrease at the end of the observation. This showed that at the beginning of observing, natural bacteria the soil can perform well because of the availability of carbon sources derived from the addition of $\mathrm{CH}_{3} \mathrm{COOH}$. The absence of addition of aluminium was also a contributing factor to the growth of natural bacteria. Based on Chau et al. (2014) under acidic condition, Al turned into soluble and toxic to microorganisms. In addition, there were differences in the total bacterial colonies in the reactor with and without the addition of V. alginolyticus. The test reactor with the addition of $V$. alginolyticus has a greater total bacterial colony compared to the reactor without the addition of $V$. alginolyticus on day 0 .

The test reactors with the addition of aluminium (V0C1 and $\mathrm{V} 0 \mathrm{C} 2$ ) tend to experience a decrease in Log CFU values until the end of the test period. This showed that the total bacterial colonies in the soil decreased with the presence of aluminium. In the reactor with the addition of $50 \mathrm{mg} / \mathrm{L}$ (V0C1) there was an increase in the Log CFU value on the $4^{\text {th }}$ day but decreased until the $12^{\text {th }}$ day. This showed that the bacteria were still able to grow until the $4^{\text {th }}$ day, but the growth started to be inhibited after the $4^{\text {th }}$ day of test period. In the reactors with the addition of a larger Al (V0C2), the number of bacterial colonies tended to decrease until the $12^{\text {th }}$ day. This showed that at greater aluminium concentration $(100 \mathrm{mg} / \mathrm{L})$, the greater inhibition of bacterial growth occurred.

The Log CFU value in the test reactor with the addition of $V$. alginolyticus and without aluminium $(\mathrm{V} 1 \mathrm{C} 0, \mathrm{~V} 2 \mathrm{C} 0$, and $\mathrm{V} 3 \mathrm{C} 0)$ tended to have the same bacterial growth trend. However, on the $8^{\text {th }}$ day until the end of the test period, the number of bacterial colonies decreased. This showed that bacterial colonies increased up to the $4^{\text {th }}$ day because they were able to process growth from the addition of carbon sources. Bacteria were still able to grow by degrading the nutrients contained in the soil. However, there was a gradual competition between bacteria due to the increasing number of bacteria and limited nutrition. Limited nutrition occurred due to the addition of carbon source conducted only at the beginning of the test period.

The test reactors with the addition of bacteria $(2 \%, 5 \%$, and $10 \%)$ and $\mathrm{Al}(50$ and $100 \mathrm{mg} / \mathrm{L}$ aluminium) tend to have the same trend. Bacterial colonies decrease until the end of the test period. This is in line with Prajitno (2017) which stated that most of the added bacteria cannot survive under polluted conditions. This is caused by the competition of nutrition and environmental conditions that do not support the bacterial growth. 


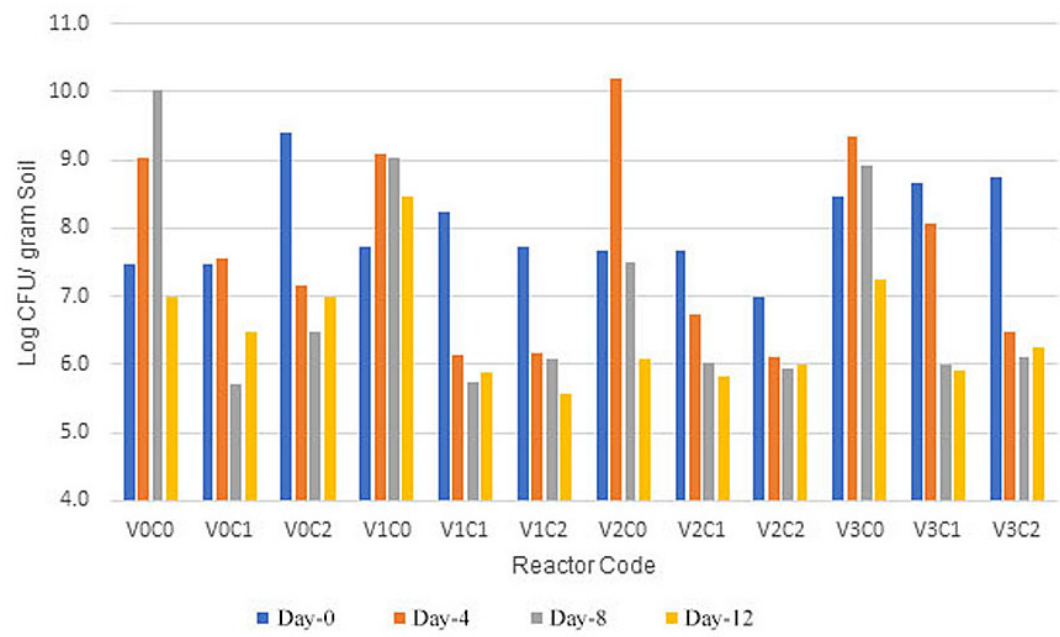

Figure 2. Number of bacterial colonies during removal of aluminium test

He et al. (2012) also stated that the addition of aluminum to the soil can reduce the amount and diversity of microbes in the soil.

On the basis of Figure 3 it can be seen that the percentage of aluminum removal in the reactor without the addition of $V$. alginolyticus and without aluminium (V0C0) tend to remain constant. On the addition of 50 and $100 \mathrm{mg} / \mathrm{L}$, the aluminum removal was $1.73 \%$ and $1.77 \%$. This indicated that the aluminum removal tends to be very small. It can be said that there was no removal of aluminum by natural bacteria. On the other hand, there can be a physical deposition of $\mathrm{Al}$ ions in the $\mathrm{V} 0 \mathrm{C} 1$ and $\mathrm{V} 0 \mathrm{C} 2$ reactors. This case occurred due to the increasing of the $\mathrm{pH}$ range significantly to neutral conditions during the test ( $\mathrm{pH} 7.0-8.0$ ).

The reactor with the addition of $100 \mathrm{mg} / \mathrm{L}$ aluminum has the highest removal percentage of $5.48 \%, 3.60 \%$, and $4.63 \%$ (V1C2, $\mathrm{V} 2 \mathrm{C} 2, \mathrm{~V} 3 \mathrm{C} 2$ respectively). The minimum removal percentage occurred in the reactor with the addition of 5\% $\mathrm{v} / \mathrm{v}$ of $V$. alginolyticus and without the addition of aluminium ( $\mathrm{V} 2 \mathrm{C} 0$ ) which only reached $2.0 \%$. This percentage of removal has a greater value compared to the reactor without the addition of $V$. alginolyticus.

The reactor with the addition of $V$. alginolyticus showed a tendency to increase the percentage of aluminum removal. On Figure 2 indicates that the number of $V$. alginolyticus colony exhibited a decreasing trend at the end of the test period. The V1C2 reactor with the largest percentage of removal experienced the largest decrease in total bacterial colonies compared to other test reactors which reached $27.93 \%$. The minimum $\mathrm{Al}$ removal (V2C0) test reactor also experienced a decrease in total bacterial colonies by $20.7 \%$ at the end of the test period. The results also showed that the addition of $V$. alginolyticus had no significant effect on the removal of aluminium from contaminated soil.

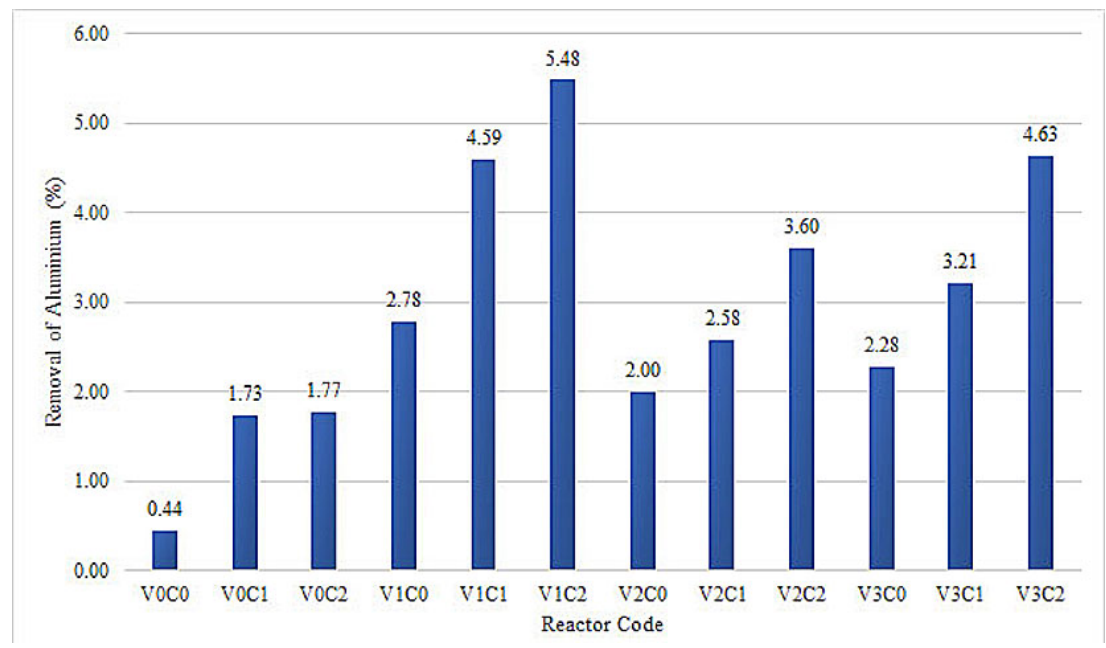

Figure 3. Removal of aluminium from contaminated soil 


\section{CONCLUSION}

Preliminary toxicity test showed that Vibrio alginolyticus was still able to grow at the addition of $50 \mathrm{mg} / \mathrm{L}$ aluminium equal $24 \mathrm{mg} \mathrm{Al} / \mathrm{kg}$ soil. Addition of 100 to $350 \mathrm{mg} / \mathrm{L}$ aluminium can inhibit the growth of $V$. alginolyticus, while the addition of $500 \mathrm{mg} / \mathrm{L}$ aluminium equal $235 \mathrm{mg} \mathrm{Al} / \mathrm{kg}$ soil can totally inhibit bacterial growth. The addition of $2 \% \mathrm{v} / \mathrm{v}$ of $V$. alginolyticus can remove $5.48 \%$ aluminium from $100 \mathrm{mg} / \mathrm{L}$ initial contaminated soil concentration during 12 days of test period. The addition of $V$. alginolyticus had no significant effect on the removal of aluminium from contaminated soil.

\section{REFERENCES}

1. Akbarzadeh N., Shariati M. 2014. Aluminium remediation from medium by Dunaliella. Ecological Engineering, 67(9), 76-79.

2. Chau Ngo Thi Tuoong, Thien Le Van, Kanazawa Shinjiro. 2014. Identification and Characterization of Acidity-Tolerant and Aluminium-Resistant Bacterium Isolated from Tea Soil. African Journal of Biotechnology, Vol. 13, 2715-2726.

3. Giovanell P., Cabral, L., Costa A.P. 2017. Metal Resistance Mechanism in Gram-negative Bacteria and their Potential to Remove $\mathrm{Hg}$ in the Presence of Other Metals. Ecotoxicology and Environmental Safety, Vol. 140, 162-169.

4. Hamdi H., Benzarti S., Manusadzianas L., Aoyama I., Jedidi, M. 2007. Bioaugmentation and Biostimulation Effects on PAH Dissipation and Soil Ecotoxicity Under Controlled Conditions. Soil Biology and Biochemistry, Vol. 39, 1926-1935.

5. Kubyshkina G., Zupančič B., Štukelj M., Grošel D., Marion L., Emri I. 2011. The Influence of Different Sterilization Techniques on the Time-Dependent Behaviour of Polyamides. Journal of Biomaterials and Nanobiotechnology 2 (1), 361-368.

6. Kumar A., Bisht B.S., Joshi, V.D. 2010. Biosorption of Heavy Metals by Four Microbial Species, Bacillus spp., Pseudomonas spp., Staphylococcus spp., and Aspergillus niger. Journal of Biology Environemntal Science Vol 4 (12), 97-108.

7. Kurniawan S.B., Purwanti I.F., Titah H.S. 2018. The Effect of $\mathrm{pH}$ and Aluminium to Bacteria Isolated from Aluminium Recycling Industry. Journal of Ecological Engineering 19 (3), 154-161.

8. Laksono I.D. and Muzayanah 2016. Identifikasi
Keluhan Masyarakat Akibat Industri Daur Ulang Aluminium di Kecamatan Sumobito Kabupaten Jombang. Tugas Akhir. Universitas Negeri Surabaya, Surabaya.

9. Lopez F.F., Cabrera C., Lorenzo M.L., Lopez M.C. 2002. Aluminium Levels in Convenience and Fast Food : In Vitro Study of the Absorbable Fraction. SCI Total Environment 300, 69-79.

10. Ojumu T.V., Petersen J., Searby G.E., Hansford G.S. 2006. A Review of Rate Equations Proposes for Microbial Ferrous-Iron Oxidation with a View to Application to Heap Bioleaching. Hydrometallurgy 83, 21-28.

11. Pina R.G., and Cervantes C. 1996. Microbial Interactions with Aluminium. Biometals 1996(9), 311-316

12. Purwanti I.F., Abdullah S.R.S., Hamzah A., Idris M., Basri H., Mukhlisin M., Latif M.T. 2015. Biodegradation of Diesel by Bacteria Isolated from Scirpus mucronatus Rhizosphere in Diesel-Contaminated Sand. Journal of Advanced Science (2) 1, 140-143.

13. Purwanti I.F., Kurniawan S.B., Tangahu B.V., Rahayu N.M. 2017. Bioremediation of Trivalent Chromium in Soil Using Bacteria. International Journal of Applied Engineering Research 12 (20), 9346-9350.

14. Purwanti I.F., Kurniawan S.B., Titah H.S., Tangahu B.V. 2018. Identification of Acid and Aluminium Resistant Bacteria Isolated from Aluminium Recycling Area. International Journal of Civil Engineering and Technology, 9 (2), 945-954.

15. Sugiyarto K.H. 2003. Dasar-Dasar Kimia Anorganik Logam. Graha Ilmu : Yogyakarta.

16. Tsakiridis P.E. 2012. Aluminium Salt Slag Characterization and Utilization - A Review. Journal of Hazardous Materials, vol. 217-218, 1-10.

17. Machmud M. 2001. TeknikPenyimpanan and Pemeliharaan Mikroba. Buletin Agro Bio, 4(1), 24-32.

18. He Genhe, Lin Junyue, Liu Qiang, Zhang Jingfei, Wu Jichun 2012. The effects of aluminum atress on bacterial community diversity in acidic red soils by polymerase chain reaction (PCR)-amplified restriction fragment length polymorphism. African Journal of Microbiology Research, 6(15), 3707-3715.

19. Prajitno A. 2007. Uji Sensitivitas Flavonoid Rumput Laut(Eucheumacottoni)SebagaiBioaktifAlamiTerhadap Bakteri Vibrio harveyi. Jurnal Protein, 15(2).

20. Martins M., Taborda R., Silva G., Assuncao A., Matos A.P., Costa M.C. 2012. Aluminum and Sulphate Removal by a Highly Al-Resistant Dissimilatory Sulphate-Reducing Bacteria Community. Journal of Biodegradation, 23(1), 693-703. 